\title{
光電子分光法による $\mathrm{Si}$ 表面酸化プロセス反応速度と 酸化誘起歪みの同時観察
}

\author{
小川修一 $1, *$ ・吉越章隆 ${ }^{2} \cdot$ 高桑雄二 $^{1}$ \\ ${ }^{1}$ 東北大学多元物質科学研究所 齿 980-8577 仙台市青葉区片平 2-1-1 \\ 2 日本原子力研究開発機構物質科学研究センター - - 679-5148 兵庫県佐用郡佐用町光都 1-1-1 \\ （2019年 2 月 19 日受付；2019 年 3 月 23 日掲載決定）
}

\author{
Simultaneous Observation of Si Oxidation Rate and Oxidation-induced Strain Using XPS \\ Shuichi Ogawa ${ }^{1, *}$, Akitaka Yoshigot ${ }^{2}$ and Yuji Takakuwa ${ }^{1}$ \\ ${ }^{1}$ Tohoku University, 2-1-1 Katahira, Aoba-ku, Sendai, Miyagi 980-8577 \\ ${ }^{2}$ Japan Atomic Energy Agency, 1-1-1 Kouto, Sayo-cho, Sayo-gun, Hyogo 679-5148
}

(Received February 19, 2019 ; Accepted March 23, 2019)

\begin{abstract}
Thermal oxidation of Si substrate is an indispensable process for the Si device fabrication. However, as the required $\mathrm{SiO}_{2}$ film thickness becomes thinner, the influence of oxidation induced strain cannot be ignored. We adopted realtime photoelectron spectroscopy using synchrotron radiation as a method to measure simultaneously the oxidation induced strain and oxidation rate at the same place. Strain causes a photoelectron spectral shift of the inner shell, so we qualitatively estimated the strain from the shift amount. Using the spectral shifts, we found that there is a correlation between the strain and the $\mathrm{SiO}_{2} / \mathrm{Si}$ interface oxidation reaction rate. It also revealed that the interfacial oxidation accelerating effect is also obtained by thermal strain due to rapid temperature rise. These results can be explained by our proposed model in which point defects caused by strain become reaction sites at the $\mathrm{SiO}_{2} / \mathrm{Si}$ interface.
\end{abstract}

KEYWORDS : thermal oxidation, real-time XPS, oxidation-induced strain, thermal strain, point defect generation

\section{1.はじめに}

ケイ素 $(\mathrm{Si})$ ベースの Metal-Oxide-semiconductor 型電 界効果トランジス夕（MOSFET）は，電子および光学産 業用アプリケーションにおいて中心的な役割を果たして いる。この MOSFET において, ゲート絶縁膜と Si の界 面には $\mathrm{Si}$ 基板の熱酸化で形成した $\mathrm{SiO}_{2}$ 膜が必要不可欠 である。このような重要性から, Si 熱酸化の研究は多く の研究者によって行われ, 膨大な数の論文が発表されて きた。その中でも B. E. Deal と A. S. Groveによって提 案された $\mathrm{Si}$ 熱酸化反応モデル (Deal-Grove モデル) ${ }^{1)}$ が 現在も重要な指針として用いられ続けている。Deal-

†2018 年日本表面真空学会学術講演会（2018 年 11 月 19 日～21 日）にて講演

*E-mail : ogasyu@tohoku.ac.jp
Grove モデルでは, $\mathrm{Si}$ 基板上における熱酸化での $\mathrm{SiO}_{2}$ 成長の律速反応を (1) $\mathrm{SiO}_{2}$ 膜中の $\mathrm{O}_{2}$ 分子拡散, おょ び（2） $\mathrm{SiO}_{2} / \mathrm{Si}$ 界面での反応，と仮定している。近年, プレーナー型 MOSFET だけでなく, 三次元の縦型構造 MOSFET の開発も進められ, 平坦な $\mathrm{Si}$ ウェハ表面の酸 化のみならず, $\mathrm{Si}$ ナノピラーの酸化も必要とされてい る。ナノピラーなど三次元形状の酸化では, Si 原子の消 失 ${ }^{2)}$ 酸化の自己停止 ${ }^{3,4)}$ な゙, Deal-Grove モデルでは予 測されなかった現象が観測されている。

このような現象を説明するため, 近年, 酸化膜成長に 伴う歪みの寄与を取り达んだ酸化反応モデルが提案され ている。 $\mathrm{Si}$ の亜酸化物は $\mathrm{SiO}_{2} / \mathrm{Si}$ 界面に集中して存在 し，また $\mathrm{sp}^{3}$ 共有結合である $\mathrm{Si}-\mathrm{Si}$-Si 結合角は $109.5^{\circ}$ が 最安定である。そのため, Si-Si 結合中に O 原子が挿入 されることによって $\mathrm{SiO}_{2} / \mathrm{Si}$ 界面には数 $\mathrm{GPa}$ の極めて大 
きな応力 ${ }^{5}$ が発生する。この応力による歪みを緩和する ために基板から酸化膜中に $\mathrm{Si}$ 原子が放出され，この歪 み緩和が界面反応を律速するというモデルが提案され だ。特に放出 $\mathrm{Si}$ 原子や原子が抜けた空孔は未結合手を 持つために化学的に活性であり, $\mathrm{SiO}_{2} / \mathrm{Si}$ 酸化の反応サ イトになるというモデル7や, 放出 $\mathrm{Si}$ 原子が $\mathrm{Si}$ 酸化物 の還元も引き起こすモデルも報告されている8。これら のモデルの妥当性を確かめるためには, 歪みと酸化速度 の相関を実験的に求めれば良い。過去には片持ちはり状 の $\mathrm{Si}$ ウェハの片面を酸化し, ウェ八の反りとエリプソ メトリによる膜厚の時分割観察により歪みと酸化速度の 同時計測が行われた9)。しかしながら, 現在デバイスの 主流となっている厚さ $1 \mathrm{~nm}$ 以下の極薄酸化膜領域での 歪みと酸化速度の計測は従来のこれらの方法では極めて 難しい。また酸化誘起応力は膜厚が薄くなるにしたがっ て増加するため ${ }^{9}$, 応力の大きな極薄酸化膜領域での実 測が必要とされてきた。

膜厚 $1 \mathrm{~nm}$ 以下の極薄酸化膜領域における歪みと酸化 速度の同時計測を行うため, 我々は放射光を用いたリア ルタイム光電子分光を用いることを提案した7)。歪みに よって Si-Si 結合長が伸縮すると, それに依存して $\mathrm{Si}$ の 内殼スペクトル位置がシフトする。このシフトした成分 から酸化誘起歪みを定性的に求めることができる。本稿 では, Si 表面酸化プロセスに打ける酸化誘起歪みと反応 速度の相関関係を本手法で明らかにした研究10), および 急昇温により発生した熱歪みによる界面酸化促進機構の 解明の研究 ${ }^{11}$ を紹介する。

\section{2. 実験および光電子スペクトル解析方法}

放射光を用いたリアルタイム光電子分光測定は SPring-8の原子力研究開発機構専用ビームライン BL23SU に設置されている表面化学実験ステーションで 行なった。本装置の測定室には $5 \times 10^{-4} \mathrm{~Pa}$ 程度まで $\mathrm{O}_{2}$ ガスを導入可能であり, 高温試料の酸化反応中に光電子 分光測定をリアルタイムで行うことができる。簡易的な ウェット洗浄した Si ウェハを測定室まで搬送し, $10^{-8}$ $\mathrm{Pa}$ の超高真空下で $950^{\circ} \mathrm{C}$ のアニールを 10 分間行い, 清 浄 $\mathrm{Si}(001) 2 \times 1$ 表面を得た。放射光エネルギーは $710 \mathrm{eV}$ で, 光電子のテイクオフ角度は $20^{\circ}$ の表面敏感条件で測 定した。酸化反応中に Si 2 p と O $1 \mathrm{~s}$ 光電子スペクトル を繰り返し測定した。

測定した清浄 $\mathrm{Si}$ 表面と酸化 $\mathrm{Si}$ 表面の $\mathrm{Si} 2 \mathrm{p}_{3 / 2}$ 光電子 スペクトルを Fig. 1 に示す。本スペクトルは Shirley 型 のバックグラウンドを除去したのち，フーリエ変換を用 いて Si $2 \mathrm{p}_{1 / 2}$ 成分を差し引いた ${ }^{12)}$ 。清浄表面には $\mathrm{Si}$ バル クピークに加え, アップ／ダウンダイマー由来のピーク

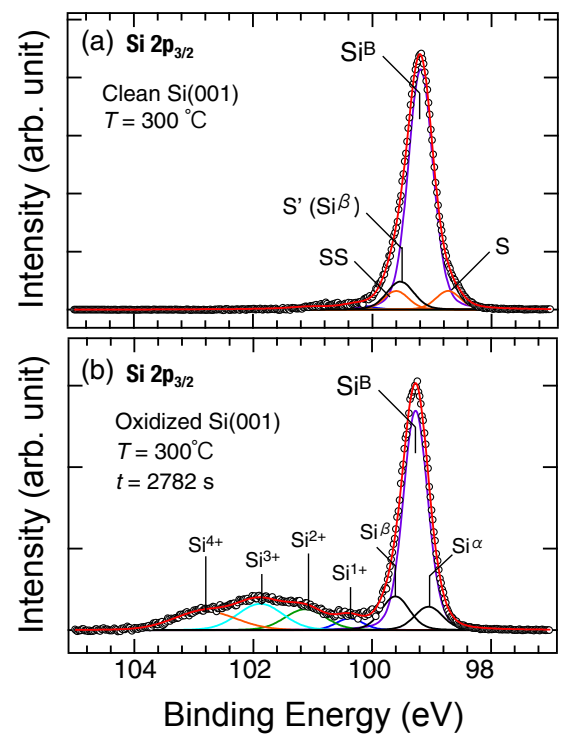

Fig. 1. (color online). Peak decomposition analysis of $\mathrm{Si}$ $2 \mathrm{p}_{3 / 2}$ spectra on (a) clean $\mathrm{Si}(001) 2 \times 1$ surface and (b) oxidized $\operatorname{Si}(001)$ surface.

（S および SS）が見られる ${ }^{13)}$ 。また $\mathrm{Si}(001)$ 表面の $2 \times 1$ 再構成に伴い, 表面から二層目の $\mathrm{Si}$ 原子層に歪みが生

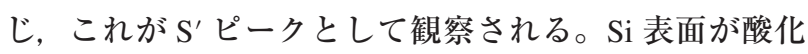
されて完全に酸化膜で覆われると, Fig. 1（b）に示すよ うにダイマー由来のピークは消失し, 酸化物 $\left(\mathrm{Si}^{1+}\right.$, $\left.\mathrm{Si}^{2+}, \mathrm{Si}^{3+}, \mathrm{Si}^{4+}\right)$ と歪んだ $\mathrm{Si}$ 原子のピーク $\left(\mathrm{Si}^{\alpha}, \mathrm{Si}^{\beta}\right)$ が現れる。歪みにより $\mathrm{Si}^{\alpha}$ と $\mathrm{Si}^{\beta}$ が観察されることは, コアレベルシフトと Si-Si 結合距離との単純な相関によ って理解できる。Si-Si 結合の伸長は結合間の局所電子 密度を減少させ高い結合エネルギーとなり, 逆に圧縮歪 みでは低い結合エネルギーを示す ${ }^{14)} 。 こ の \mathrm{Si}^{\alpha}, \mathrm{Si}^{\beta}$ は $\mathrm{SiO}_{2} / \mathrm{Si}$ 界面に局在していることが光電子回折測定から 明らかになってお $り^{15,16)}$, 雨ピーク強度は酸化誘起歪み の定性的指標として利用可能である。

一方で $\mathrm{Si}^{\alpha}, \mathrm{Si}^{\beta}$ ピークのシフト量は $\pm 0.3 \mathrm{eV}$ 程度と小 さく, 酸化物ピークのように肩構造やピーク分裂も見ら れない。すなわち, $\mathrm{Si}^{\alpha}$ と $\mathrm{Si}^{\beta}$ を考虑しなくても $\mathrm{Si}$ バル クピークのみでスペクトルを再現できる可能性がある。 しかし, 清浄表面から酸化表面まで時間的に連続した $\mathrm{Si} 2 \mathrm{p}$ スペクトルの解析において, $\mathrm{Si}^{\alpha}$ と $\mathrm{Si}^{\beta}$ ピークなし では $\mathrm{Si}$ バルクピークの半值幅一定条件では再現よくフ イッティングできなかった。これは逆に, 酸化の進行に 応じて $\mathrm{Si}$ バルクピークの半值幅を大きくしていけば $\mathrm{Si}^{\alpha}$ と $\mathrm{Si}^{\beta}$ を取り込まなくても Si $2 \mathrm{p}$ スペクトルを再現でき ることを示すが, 基板温度や測定条件が変わらなければ その半值幅も変わらないはずである。酸化の進行に伴う バルクピークの半值幅増大に物理的意味はなく, 半值幅 
が増大したように見えるのはその近傍に新たなピークが 出現したと考えるのが自然である。このようにリアル夕 イム光電子分光では $\mathrm{Si}$ バルクピークの半值幅を常に一 定という条件を課すことにより, 歪みの評価を行うこと が可能になる。本研究では $\mathrm{Si}$ バルクピークのガウス関 数半值全幅を $0.44 \mathrm{eV}$, ローレンツ関数半值全幅を 0.10 $\mathrm{eV}$ とした。その他のパラメータは文献 ${ }^{10} に$ 示す。

\section{3. 結 果 と考 察}

\section{1 界面酸化速度と酸化誘起歪みの相関}

温度 $300^{\circ} \mathrm{C}$, 酸素圧力 $4.1 \times 10^{-5} \mathrm{~Pa}$ で $\mathrm{Si}(001)$ 表面を 酸化中の $\mathrm{O} 1 \mathrm{~s}$ 光電子強度と $\mathrm{Si} 2 \mathrm{p}$ スペクトルから求め た $\mathrm{Si}^{\alpha}$ と $\mathrm{Si}^{\beta}$ 成分の時間変化を Fig. 2 に示す。酸化開始 直後から O 1s 強度は急増し, 酸化開始後 1500 秒から緩 やかな増加になっている。このような指数関数型の時間 変化は, $\mathrm{Si}(001)$ 表面での酸化膜成長がラングミュア型 吸着で進行していることを示している。ラングミュア型 吸着による酸化膜成長シミュレーションを Fig. 2 (a) 中に実線で示す。実験結果とシミュレーションは $1700 \mathrm{~s}$ まではよく一致しているが, それ以降では両者にズレが 生じている。このズレが生じる時点に扔いて表面の $2 \times 1$ 構造は完全に消失するため ${ }^{17)}$ ，このズレは $\mathrm{SiO}_{2} / \mathrm{Si}$

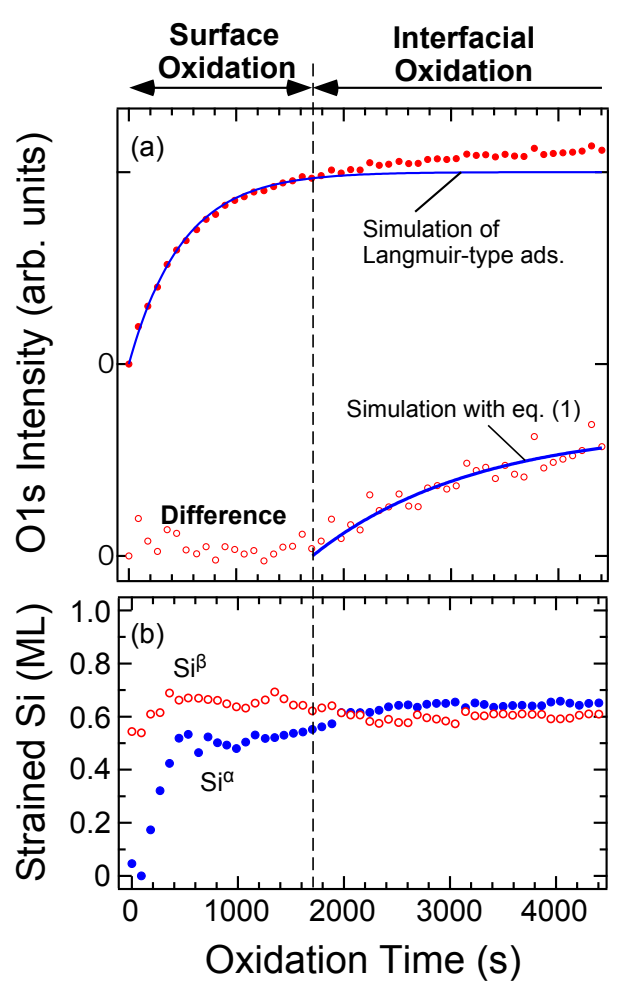

Fig. 2. (color online). Time evolution of (a) $\mathrm{O} 1 \mathrm{~s}$ intensity and difference between experimental data and simulation based on Langmuir-type adsorption, and (b) amounts of strained $\mathrm{Si}$ atoms $\left(\mathrm{Si}^{\alpha}\right.$ and $\left.\mathrm{Si}^{\beta}\right)$.
界面での酸化を示している。すなわち, $\mathrm{Si}(001)$ 表面酸 化はラングミュア型吸着の様式で進行するが，表面が完 全に酸化膜で覆われた後の界面酸化はラングミュア型吸 着とは異なる機構で進行する。

$\mathrm{O} 1 \mathrm{~s}$ 強度の時間変化とラングミュア型吸着によるシ ミュレーションの差 $\left(I_{\text {diff }}\right)$ を Fig. 2 (a) の下段に示す。 この差分から界面酸化速度 $R_{\mathrm{int}}(\mathrm{t})$ を求めるため, $I_{\mathrm{dif}}$ を以 下の式でフィッティングした。

$$
I_{\mathrm{dif}}=A_{1}\left[1-\exp \left(-k_{1} t\right)\right]+A_{2}\left[1-\exp \left(-k_{2} t\right)\right]
$$

ここで $t$ は界面酸化時間であり, 酸化時間 1702 秒が $t=0$ に相当する。式 $(1)$ を $t$ で微分し, $t=0$ を代入 すると界面酸化初期速度 $R_{\text {int }}(0)$ が求まる。すなわち,

$$
R_{\text {int }}(0)=\left.\frac{d I_{\text {Dif }}}{d t}\right|_{t=0}=A_{1} k_{1}+A_{2} k_{2}
$$

である。式（2）は二項からなるが，これは二種類の 欠陥が反応に寄与していることに対応する ${ }^{18)}$

界面酸化開始時に扔ける歪み $\mathrm{Si}$ 原子の総量と酸化速 度の相関を得るため, 酸化温度を $303^{\circ} \mathrm{C}$ から $547^{\circ} \mathrm{C}$ まで 変えて実験を行なった ${ }^{10)}$ 。 $R_{\mathrm{int}}(0)$ と界面酸化開始時にお ける $\mathrm{Si}^{\alpha}, \mathrm{Si}^{\beta}$ 面積強度の酸化温度依存を Fig. 3 に示す。 ここで, $\mathrm{Si}^{\alpha}$ と $\mathrm{Si}^{\beta}$ は界面酸化開始時（1702 秒）のデー 夕点に加え, 前後 2 点 (合計 5 点) のデー夕点の平均と した。Fig. 3（b）中のエラーバーは，5点のばらつきを 示すものである。 $R_{\mathrm{int}}(0)$ は $500^{\circ} \mathrm{C}$ まで単調に減少し, 他

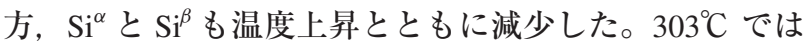
界面酸化開始直後に $0.65 \mathrm{ML}$ の $\mathrm{Si}^{\beta}$ 原子が存在したが,

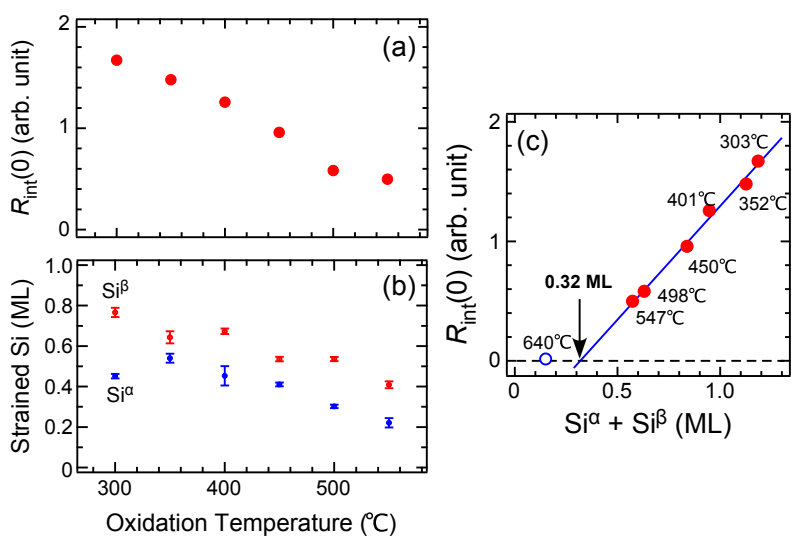

Fig. 3. (color online). Oxidation temperature dependences of (a) oxidation rate and (b) amount of strained $\mathrm{Si}$ atoms at the start of interface oxidation. (c) The amount of strained Si atoms dependence of oxidation rate. Oxidation temperatures are also shown. The closed and open circles indicate the results at the $\mathrm{SiO}_{2} / \mathrm{Si}$ interface grown by Langmuir-type adsorption and 2D oxide island growth, respectively. 
$547^{\circ} \mathrm{C}$ では $0.35 \mathrm{ML}$ 程度まで減少した。ここで $1 \mathrm{ML}$ は $\mathrm{Si}(001)$ 表面の原子面密度に相当し, $1 \mathrm{ML}=6.82 \times 10^{14}$ atoms $/ \mathrm{cm}^{-2}$ である。ML 単位での歪み $\mathrm{Si}$ 量は光電子強 度から求め, その計算方法は文献 ${ }^{10)}$ に示す。 $\mathrm{Si}^{\alpha}$ の減少 割合は $\mathrm{Si}^{\beta} よ り も 大 き く, ~ 547^{\circ} \mathrm{C}$ では $352^{\circ} \mathrm{C}$ の $1 / 3$ 程度 となっている。

このように, 表面酸化直後の界面酸化では酸化速度が 温度の上昇に伴って減少することが明らかとなった。こ の結果は Deal-Grove モデルを用いて説明できない。な ぜならば, Deal-Grove モデルでは酸化膜成長は $\mathrm{O}_{2}$ 拡散 と界面反応で律速されると考えられており, その活性化 エネルギーはそれぞれ $1.2 \mathrm{eV}$ と $2.4 \mathrm{eV}$ と正值であるた め $^{1)}$, 温度が増加するにつれて酸化反応速度は増加する はずだからである。したがって, 表面酸化から引き続い て進行する界面酸化では Deal-Grove モデルで想定され ていない過程が反応律速になっていると考えられる。 $R_{\text {int }}(0)$ と $\mathrm{Si}^{\alpha}, \mathrm{Si}^{\beta}$ の両者は似たような温度依存の傾向を 示すことから, 界面酸化では界面歪みが重要な役割を担 っていると考えられる。

$R_{\mathrm{int}}(0)$ への界面歪みの効果を定量的に調べるために, $R_{\text {int }}(0)$ と歪み $\mathrm{Si}$ 原子の総量 $\left(\mathrm{Si}^{\alpha}+\mathrm{Si}^{\beta}\right)$ の相関を Fig. 3 (c) に示す。両者の間には大変によい直線的相関が見られ る。このことから歪み Si 原子の量に比例して界面酸化 速度が増加することが分かる。ただし, その関係を外挿 すると $\left(\mathrm{Si}^{\alpha}+\mathrm{Si}^{\beta}\right)$ が $0.32 \mathrm{ML}$ で $R_{\mathrm{int}}(0)$ が 0 となっている。 このことから歪み $\mathrm{Si}$ 原子の量が $0.32 \mathrm{ML}$ 以下では, 界 面での酸化反応はほとんど進行しないことが示唆され る。実際, 高温の $640^{\circ} \mathrm{C}$ の二次元島成長領域 ${ }^{19)}$ で $\mathrm{Si}(001)$ 表面を酸化させると, 界面酸化はほとんど進行せず界面 歪みも小さかった。

この結果は，歪みによって発生した点欠陥（放出 $\mathrm{Si}$ 原子とその抜けた空孔）が $\mathrm{O}_{2}$ 分子との反応サイトにな るというモデルを用いて説明できる。点欠陥発生を介し た Si 酸化反応モデルの模式図を Fig. 4 に示す。ここで 放出される $\mathrm{Si}$ 原子は $\mathrm{Si}^{\alpha} も し く は \mathrm{Si}^{\beta}$ 自身か, その近隣

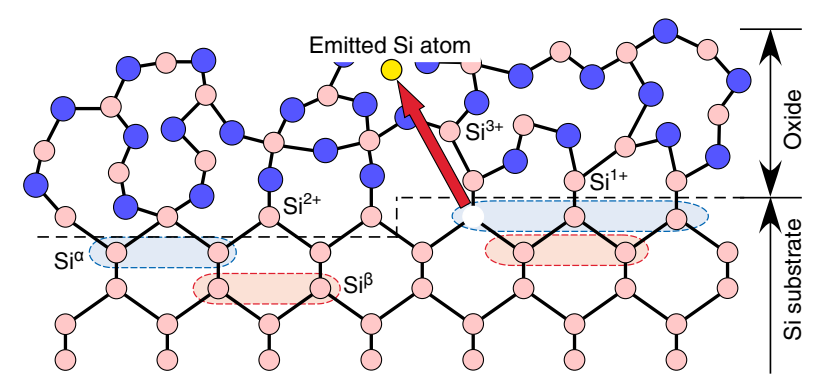

Fig. 4. (color online). Cross-sectional schematic illustration of oxide/ $\mathrm{Si}(001)$ interface. $\mathrm{Si}^{\alpha}$ and $\mathrm{Si}^{\beta}$ atoms exist in the first and second Si layers from the oxide.
原子と考えられる。これらの原子は酸化誘起応力により 大きな格子歪みを持っており, 弾性エネルギーを減少さ せるため欠陥の発生が必要である。点欠陉は未結合手を 持つため, $\mathrm{O}_{2}$ 分子に対して非常に反応性が高い。界面 歪みが大きいほど点欠陷生成が促進され，そのため界面 での酸化反応も促進されると考える。空孔は 4 本の未結 合手を持つが，未結合手は不安定なため，未結合手の本 数を減らすように格子の歪みが発生する。これによりデ バイスで問題となる未結合手による不対電子対が解消さ れ，デバイス動作で問題となる欠陥と酸化により発生す る欠陷の数は一致しない。一方, 放出 $\mathrm{Si}$ 原子も $\mathrm{SiO}_{2}$ を 形成する $\mathrm{Si}$ 原子と結合することによって未結合手を減 らす一方, $\mathrm{SiO}_{2}$ が還元され亜酸化物が形成される。こ こで, 点欠陥が発生すると界面歪みも緩和されるが, 発 生した点欠陥により $\mathrm{SiO}_{2} / \mathrm{Si}$ 界面で酸化反応が進行し, 再び酸化誘起歪みが発生する。それに加え, 未結合手を 減らすための格子変形も点欠陥を発生させる歪みの原因 となる。そのため, 表面酸化過程で蓄積された歪みの影 響は界面酸化過程においてかなり長い間残ると考えられ る。その一方, 酸化膜厚の増加に対して酸化速度は指数 関数的に減少するため, 点欠陥の発生量も膜厚の増加と ともに減少していく9 。

以上のように, 界面酸化の進行には歪みによる点欠陥 発生が不可欠であることが示唆された。点欠陥を発生す る界面歪みには酸化誘起歪みのような真性歪みと熱歪み の二種類がある。近年, Si ウェハのドーパント拡散抑制 のため, 酸素雲囲気中で $\mathrm{Si}$ ウエハ温度を短時間のうち に急昇温し, 酸化膜を形成する急速加熱酸化が着目され ている。 $\mathrm{SiO}_{2}$ と $\mathrm{Si}$ の熱膨張係数が異なるため, 急昇温 過程では大きな熱歪みが発生する。この熱歪みによる酸 化促進効果について次節で述べる。

\section{2 界面酸化速度と酸化誘起歪みの相関}

急昇温過程における熱歪みによる酸化促進効果を明ら かにするため, 温度 $T_{1}$ で $\operatorname{Si}(001)$ 表面を酸化し, 表面が 酸化膜で覆われて界面酸化に移行した時に温度を $T_{2} に$ 上昇させる実験を行なった ${ }^{11)}$ 。なお, 表面化学実験ステ ーションはヒーターを用いた傍熱加熱のために急昇温が できず，本実験には不向きである。そのため酸化速度 は, 東北大学に設置されている RHEED-AES 装置 ${ }^{17)}$ で, O KLL オージェ電子強度の時間変化から求めた。本装 置では短冊状の $\mathrm{Si}$ ウエハに直接通電し加熱するので $100^{\circ} \mathrm{C} / \mathrm{s}$ 以上の急昇温が可能である。酸化実験中におけ る O KLL オージェ電子強度の時間変化を Fig. 5 に示す。 $T_{1}=268^{\circ} \mathrm{C}$ から $T_{2}=682^{\circ} \mathrm{C}$ への温度上昇に伴って, O KLL 強度が急増している。温度上昇後の酸化速度を調 べるため，前節と同じ方法で式（1）を用いてフィッ 


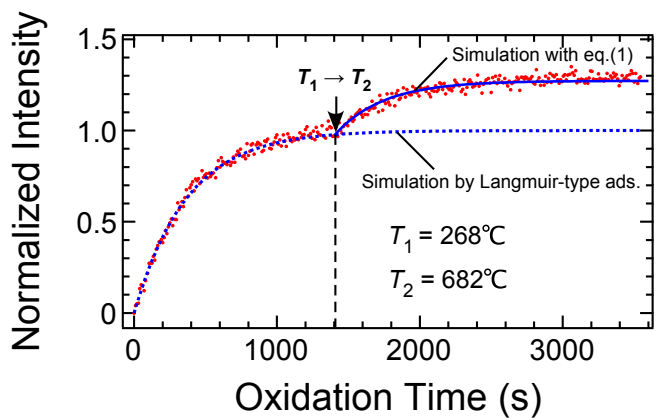

Fig. 5. (color online). Time evolution of the O KLL Auger electron intensity during oxidation with the temperature increased at $1420 \mathrm{~s}$.

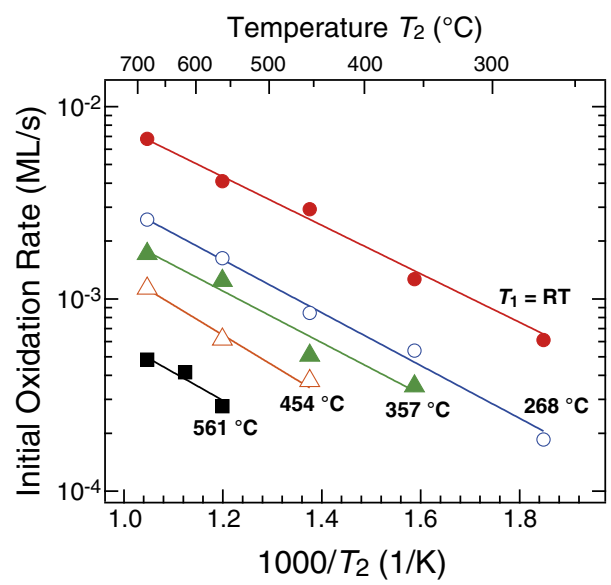

Fig. 6. (color online). Surface oxidation temperature $T_{1}$ dependence of the Arrhenius plot of the initial interfacial oxidation rate $R_{\text {int }}(0){ }^{12)}$

ティングし, 初期酸化速度を求めた。

$T_{1}$ を $\mathrm{RT}$ から $561^{\circ} \mathrm{C}$ まで変えたときの $R_{\mathrm{int}}(0)$ の $T_{2}$ に対 するアレニウスプロットを Fig. 6 に示す。全ての $T_{2}$ に おいて, $R_{\text {int }}(0)$ は $T_{1}$ が小さくなるほど大きくなる。具体 的には $T_{2}=682^{\circ} \mathrm{C}$ のとき, $T_{2}$ は同じにもかかわらず, $T_{1}$ $=\mathrm{RT}$ と $561^{\circ} \mathrm{C}$ で $R_{\mathrm{int}}(0)$ が約 10 倍も異なる。また全ての $T_{1}$ において，アレニウスプロットの傾きが一致してい ることから, 界面酸化の活性化エネルギーは $T_{1}$ に依存

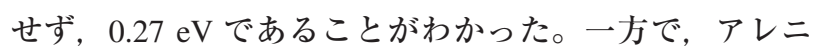
ウスプロットの切片に相当する頻度因子は $T_{1}$ の上昇と ともに減少した。 $T_{1}$ が高いほど界面酸化の律速過程の 発生頻度が小さいことを示している。

これらの実験結果について考察する。はじめに, 同じ $T_{2}$ において $T_{1}$ が低いほど $R_{\mathrm{int}}(0)$ が大きくなる結果につ いて考える。これまでの Deal-Grove モデルでは, 酸化 速度は $\mathrm{SiO}_{2} / \mathrm{Si}$ 界面における $\mathrm{O}_{2}$ 濃度（圧力）と基板温 度のみで決まると考えている。これは，本モデルにおけ る律速反応として酸化膜中の $\mathrm{O}_{2}$ 拡散と $\mathrm{SiO}_{2} / \mathrm{Si}$ 界面反

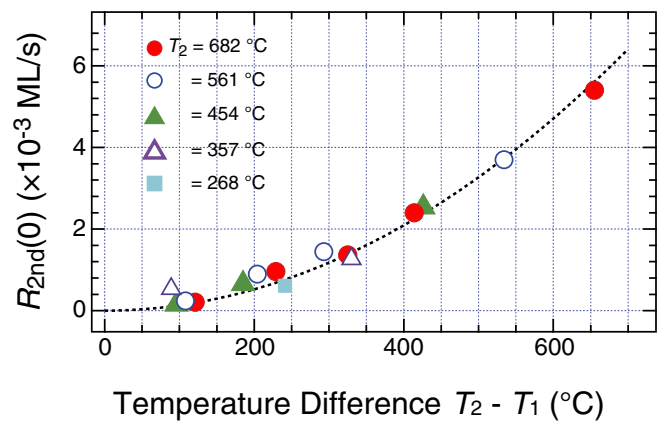

Fig. 7. (color online). Dependence of the initial interfacial oxidation rate on the temperature difference $\left(T_{2}-T_{1}\right) .{ }^{12)}$ The dotted line indicates the fitted quadratic function.

応のみとしているためである。本結果を Deal-Grove モ デルで考える場合，界面反応 $\mathrm{O}_{2}$ 分子の拡散律速を考え る必要がある。なぜなら, 界面反応の活性化エネルギー は $2.4 \mathrm{eV}$ と正の值であるため ${ }^{1)}$, 界面反応が律速であれ ば反応速度は $T_{2}$ のみに依存するが，これは本実験結果 と矛盾する。したがって， $T_{1}$ が高い条件で厚い $\mathrm{SiO}_{2}$ 膜 が形成され， $R_{\text {int }}(0)$ が減少したと解釈する必要がある。 しかしながら, 表面酸化完了後の酸化膜厚はXPS で求 めることができ, その結果, $T_{1}=145^{\circ} \mathrm{C}$ で $0.35 \mathrm{~nm}$, $600^{\circ} \mathrm{C}$ でも $0.50 \mathrm{~nm}$ であった ${ }^{11)} 。 T_{1}$ が高くなっても表面 酸化完了後の酸化膜厚はわずか 1.4 倍にしかならないた め, Deal-Grove モデルに押ける $\mathrm{O}_{2}$ 拡散では $R_{\mathrm{int}}(0)$ が 10 倍になることを説明できない。なぜなら， $\mathrm{O}_{2}$ 拡散律速 であれば $R_{\mathrm{int}}(0)$ は膜厚に比例するからである。したがっ て, 急昇温による界面酸化促進では $\mathrm{O}_{2}$ 拡散以外の律速 過程の存在が示唆される。

我々のモデルでは, 温度変化による熱歪みにより点欠 陥発生が増加し，反応サイトとなる点欠陥が増えたため に $R_{\text {int }}(0)$ が増加すると考える。熱歪みは，異なる固体の 接合部分において温度が変化すると熱膨張係数が異な るために界面に発生する歪みである。このとき，歪みエ ネルギーは温度差の二乗に比例する ${ }^{11)} 。 R_{\text {int }}(\mathrm{t})$ と温度差 $\left(T_{2}-T_{1}\right)$ の相関を Fig. 7 に示す。様々な $T_{2}$ や $T_{1}$ に関わ らず， $R_{\mathrm{int}}(0)$ は温度差の二次関数でよくフィッティング できる。点欠陥の発生量が歪みエネルギーに比例すると 仮定すれば，我々の点欠陥発生モデルを用いて急昇温過 程での反応も説明できる。

このモデルに基づくと点欠陥生成が界面酸化の律速反 応である。したがって, Fig. 6 から求められた $0.27 \mathrm{eV}$ は点欠陥発生の活性化エネルギーであると示唆される。 一方で, $\mathrm{Si}$ バルク中では 4 本の $\mathrm{Si}-\mathrm{Si}$ 結合を切断し放出 $\mathrm{Si}$ 原子を生成するためには $3.6 \mathrm{eV}$ の障壁がある。この 異なる活性化エネルギーの要因として，酸化による発熱 
の寄与が推測される。Pauling による結合エネルギーの 值 ${ }^{20)}$ である $\mathrm{Si}-\mathrm{Si}(1.83 \mathrm{eV}), \mathrm{Si}-\mathrm{O}(3.82 \mathrm{eV}), \mathrm{O}-\mathrm{O}(5.12$ $\mathrm{eV})$ を用いて, $\mathrm{Si}-\mathrm{Si}$ と $\mathrm{O}_{2}$ から $\mathrm{Si}-\mathrm{O}-\mathrm{Si}$ 結合を形成する ときに発生するエネルギーは $3.3 \mathrm{eV}$ と求まる。つまり, Si-O-Si 結合エネルギー $(3.82 \mathrm{eV} \times 2)$ から, Si-Si 結 合の切断 $(1.83 \mathrm{eV})$ と $\mathrm{O}$ 原子を一つ作るエネルギー $(2.56 \mathrm{eV})$ の差分 $(3.25 \mathrm{eV})$ を吸着熱と考えた。このエ ネルギーが Si 結晶中に散逸せず，局所的な加熱に用い られると仮定すると， $3.6 \mathrm{eV}$ (バルク中の点欠陷発生） と発熱 $(3.3 \mathrm{eV})$ との差分により酸化が関連する点欠陥 発生の活性化エネルギーは約 $0.3 \mathrm{eV}$ 程度と見積もるこ とができ, 本研究で求めた $0.27 \mathrm{eV}$ と近い值となる。以 上のことから, $\mathrm{SiO}_{2} / \mathrm{Si}$ 界面での酸化反応において, 未 結合手をもつ欠陷の発生が重要なファクターであると考 えられる。

\section{4. ま め}

我々は歪みと酸化速度を同時に測定する方法として, 放射光を利用したリアルタイム光電子分光法を採用し た。歪みにより Si 内殼スペクトルのシフトが生じるた め, そのシフトしたスペクトル強度から酸化誘起歪みを 定性的に見積った。この手法を用いて, 歪みと $\mathrm{SiO}_{2} / \mathrm{Si}$ 界面酸化速度に相関があることを見出した。また急昇温 による熱歪みによっても界面酸化促進効果があることを 明らかにした。これらの実験結果を統一的に説明するた めに, 歪みによって発生する点欠陥（放出 $\mathrm{Si}$ 原子十空 孔）が酸化反応サイトになるというモデルを提案した。 光電子スペクトルのシフトから歪みを求める手法は, 金 属でも応用できるため, 機械的歪み印加による触媒効率 向上など歪みを用いた反応制御の解明などに活用できる と期待される。

\section{謝辞}

実験にご協力いただきました寺岡有殿博士（量研 機構), 石塚眞治博士 (秋田高専), 唐佳芸博士（兵 庫県立大) に感謝いたします。本研究はJSPS 科研費 (JP16H05969, JP17KK0125), および「物質・デバイス 領域共同研究拠点」の助成を受けました。本研究の 一部はナノテクノロジープラットフォームの支援を受 けて実施されました。放射光実験は SPring-8で行いま した（課題番号：2017A3836，2017B3836，2018A3801,
2018A3836, 2018B3801, 2018B3836)。

\section{文 献}

1) B.E. Deal and A.S. Grove : J. Appl. Phys. 36, 3770 (1965).

2) H.I. Liu, D.K. Biegelsen, N.M. Johnson, F.A. Ponce and R.F.W. Pease : J. Vac. Sci. Technol., B 11, 2532 (1993).

3) H.I. Liu, N.I. Maluf, R.F.W. Pease, D.K. Biegelsen, N.M. Johnson and F.A. Ponce : J. Vac. Sci. Technol., B 10, 2846 (1992).

4) H.I. Liu, D.K. Biegelsen, F.A. Ponce, N.M. Johnson and R.F.W. Pease : Appl. Phys. Lett. 64, 1383 (1994).

5) R.J. Jaccodine and W.A. Schlegel : J. Appl. Phys. 37, 2429 (1966).

6) H. Kageshima and K. Shiraishi : Phys. Rev. Lett. 81, 5936 (1998).

7) S. Ogawa, A. Yoshigoe, S. Ishidzuka, Y. Teraoka and Y. Takakuwa : Jpn. J. Appl. Phys. 46, 3244 (2007).

8) S. Ogawa and Y. Takakuwa : Jpn. J. Appl. Phys. 45, 7063 (2006).

9) E. Kobeda and A. Irene : J. Vac. Sci. Technol., B 7, 163 (1989).

10) S. Ogawa, J. Tang, A. Yoshigoe, S. Ishidzuka, Y. Teraoka and Y. Takakuwa : Jpn. J. Appl. Phys. 52, 110128 (2013).

11) S. Ogawa, J. Tang, A. Yoshigoe, S. Ishidzuka and Y. Takakuwa : J. Chem. Phys. 145, 114701 (2016).

12) 高桑雄二編 : “X 線光電子分光法（分光法シリー ズ)”(講談社, 2018).

13) E. Landemark, C.J. Karlsson, Y.-C. Chao and R.I.G. Uhrberg : Phys. Rev. Lett. 69, 1588 (1992).

14) O.V. Yazyev and A. Pasquarello : Phys. Rev. Lett. 96, 157601 (2006).

15) S. Dreiner, M. Schürmann and C. Westphal : Phys. Rev. Lett. 93, 126101 (2004).

16) S. Dreiner, M. Schürmann, M. Krause, U. Berges and C. Westphal : J. Electron Spectrosc. Relat. Phenom. 144-147, 405 (2005).

17) S. Ogawa, J. Tang and Y. Takakuwa : AIP Adv. 5, 087146 (2015).

18) S. Ogawa and Y. Takakuwa : AIP Adv. 8, 075119 (2018).

19) S. Ogawa, A. Yoshigoe, S. Ishidzuka, Y. Teraoka and Y. Takakuwa: Thin Solid Films 508, 169 (2006).

20) L.C. Pauling : "The Nature of the Chemical Bond and the Structure of Molecules and Crystals" (Cornell Univ Pr., 1960). 